\title{
Effect of Various Kinds of Dietary Proteins In Semi - Artificial Diets on the Mulberry Silkworm Bombyx mori L.
}

\author{
Mona M. Mahmoud
}

Dep. of Sericulture, Plant Protection Res. Institute, ARC, Alexandria, Egypt.

\begin{abstract}
Larvae of Bombyx mori were reared on various kinds of dietary protein (soybean, mushroom and mixture of them) using semi-artificial diet. Larvae fed on semi-artificial diet containing soybean all over the $5^{\text {th }}$ instar larvae gave the highest records on the larval duration, weights of larvae, silk gland, pupa, cocoon and cocoon shell, as well as number of deposited eggs. The same diet gave the lowest mortality percentages. The lower weights were calculated from larvae fed on mushroom diet. Insignificant differences were recorded on the pupal stage duration. Same trend of results were indicated for the larvae fed on the same materials till the $5^{\text {th }}$ day of the last instars then fed on natural diet.
\end{abstract}

\section{INTRODUCTION}

Mulberry is the primary host plant of silkworm Bombyx mori L. which is exploited on commercial scale for production of silk. The aim of the sericulturist is to improve the production of silk quantitatively and qualitatively.

Silkworm is a highly sensitive insect and responds sharply to changes in the feed quality. The effects of various kinds of dietary protein on growth of the silkworm Bombyx mori L. were determined using semi-synthetic diets. Ito and Inokuchi, (1981) and Horie and Watanabe, (1983) found that larval growth was largely dependent on the dietary proteins.

In (1960) Fukuda et al., succeeded to rear silkworm Bombyx mori on artificial diet for a long time. Akhtar and Asghar, (1972) used casein or its component amino acids mixture as a source of protein in the semi-synthetic diet for silkworm Bombyx mori larvae. Horie and Watanabe (1983) found that the increase in the body weight of the silkworm larvae and fresh silk glands were largest in the larvae fed on soybean meal diet. Moustafa et al (1997) studied the nutritional effect of tested level of mulberry leaf powder and dietary soybean in the semi-artificial diet. El-Sayed (1999) and El-Hattab (2002) studied the evaluation of various kinds of proteins in semiartificial diets of Bombyx mori larvae on some bio-physiological parameters.

The objective of the present work is to study the effect of two sources of protein (soybean and mushroom) and their mixture in semi-artificial diet on some biological parameters and the productivity of the silkworm Bombyx mori L.

\section{MATERIALS AND METHODS}

The tested dietary proteins used in this study were as follows:

1- Soybean meal powder (Table, 1).

2- Oyster mushroom powder instead of soybean powder.

3- $5 \mathrm{~g}$. of soybean powder $+5 \mathrm{~g}$. of oyster mushroom powder.

The eggs of mulberry silkworm Bombyx mori L. were reared in the laboratory according to the standard rearing technique as advocated by Krishnaswami (1973) 
under the hygrothermic conditions of $26 \pm 1.5^{\circ} \mathrm{c}$ and $75 \pm 5 \%$ R.H. The larvae were fed on fresh clean mulberry leaves variety Romi until $4^{\text {th }}$ instar. Only the last larval instar was used in the experiment. The larvae were grouped, since the first group was fed by the various tested dietary proteins in semi-artificial diet all over the fifth larval instar. The second group was fed on the same materials till the fifth day of the last instar then fed on the natural diet. The basic dietary ingredients chosen in this work were those used by Fukuda (1963), Salem (1974) and El-Hattab (1985) in Table 1.

Table (1): component of the basic semi-artificial diet.

\begin{tabular}{|l|l|}
\hline Constituents & $(\mathrm{g})$. \\
\hline Dried powder of mulberry leaves & 55 \\
Sugar & 10 \\
Soybean meal powder & 10 \\
Agar-agar powder & 15 \\
Sodium dihydro acetic acid & 0.54 \\
Water & $270 \mathrm{ml}$. \\
\hline
\end{tabular}

\section{Nutritional Value of materials used:}

\section{a. Soybean powder:}

In Table 2 according to USDA every (100 g.) soybean powder contains:

Table (2): Approximate Nutritional Value for (100 g.) Soybean Powder.

\begin{tabular}{|l|l|}
\hline Calories & $446 \mathrm{kcal}$ \\
\hline Protein & $36.49 \%$ \\
\hline Fat & $19.94 \mathrm{~g}$. \\
\hline Vitamin B2 (Riboflavin) & $0.377 \mathrm{mg}$. \\
\hline Vitamin C & $6 \mathrm{mg}$. \\
\hline Vitamin K & $47 \mu \mathrm{g}$. \\
\hline Fiber & $9.3 \mathrm{~g}$. \\
\hline Carbohydrate & $30.16 \mathrm{~g}$. \\
\hline Phosphorus & $704 \mathrm{mg}$. \\
\hline Calcium & $277 \mathrm{mg}$. \\
\hline Iron & $15.7 \mathrm{mg}$. \\
\hline
\end{tabular}

\section{b. Oyster mushroom powder:}

In Table 3 according to County Line Mushrooms every (100g.) mushroom powder contains:

Table 3: Approximate Nutritional Value for (100g.) Oyster Mushrooms Powder.

\begin{tabular}{|l|l|}
\hline Calories & $38 \mathrm{kcal}$. \\
\hline Protein & $15-25 \%$ \\
\hline Fat & $2.2 \mathrm{~g}$. \\
\hline Vitamin B1 (Thiamine) & $0.56 \mathrm{mg}$. \\
\hline Vitamin B2 (Riboflavin) & $0.55 \mathrm{mg}$. \\
\hline Vitamin B3 (Niacin) & $12.2 \mathrm{mg}$. \\
\hline Fiber & $2.8 \mathrm{~g}$. \\
\hline Carbohydrate & $6.5 \mathrm{~g}$. \\
\hline Phosphorus & $140 \mathrm{mg}$. \\
\hline Calcium & $28 \mathrm{mg}$. \\
\hline Iron & $1.7 \mathrm{mg}$. \\
\hline
\end{tabular}

\section{Estimation of the studied parameters:}

The experiment was designed on the basis of three replicates for each treatment. Each replicate contained 50 newly ecdysed $5^{\text {th }}$ instar larvae. The different 
prepared diets were offered to the tested larvae in the form of slices. The durations of larvae and pupae were recorded, and the percentage of larval mortality was calculated.

The fresh weights of silk glands, pupae, cocoons and cocoon shells were determined. The number of deposited eggs/female moth were counted and recorded. Statistical analysis of data was performed on the basis of the mean values plus or minus standard deviation. Data were statistically analyzed and compared using "F" test, Least Significant Difference (L.S.D.) at 5\% probability level, (Sendecor, 1956) and "T" test.

\section{RESULTS AND DISCUSSION}

\section{Effect of the tested materials on biological parameters of the silkworm Bombyx} mori L.:

The results presented in Table 4, show that the mean weights of the mature larvae, silk gland and pupa were significantly different. It is found that larvae fed on diet containing soybean (S) gave the heaviest weights of larvae, silk gland and pupa $(3.49,0.425$ and 1.054 g. respectively). On the other hand the lightest weights (2.822, 0.301 and $0.875 \mathrm{~g}$. in respect) were indicated by the diet containing mushroom powder (M).

Table 4, shows that the shortest duration of the fifth larval instar and larval duration were (10 and 33 days respectively) and that was recorded for those larvae fed on (M) diet, followed by, larvae fed on (S) diet and their mixture.

As shown in Table, 4 the duration of pupal stage for all tested materials were about 14 days.

Table 4: Effect of tested materials in semi-artificial diet on the inspected biological parameters of Bombyx mori L.

\begin{tabular}{|c|c|c|c|c|c|c|}
\hline Treatments & $\begin{array}{c}\text { Weight of } \\
\text { larvae (g.) } \\
\text { A } \\
\end{array}$ & $\begin{array}{c}5^{\text {th }} \text { instar } \\
\text { duration } \\
\text { (days) }\end{array}$ & $\begin{array}{c}\text { Larval } \\
\text { duration } \\
\text { (days) }\end{array}$ & $\begin{array}{l}\text { Weight of } \\
\text { silk gland } \\
\text { (g.) B }\end{array}$ & $\begin{array}{c}\text { Weight of } \\
\text { pupa (g.) } \\
\text { A } \\
\end{array}$ & $\begin{array}{c}\text { Pupal } \\
\text { duration } \\
\text { (days) }\end{array}$ \\
\hline $\mathbf{S}$ & $\begin{array}{c}3.490 \\
\mathrm{a} \\
\pm 0.279 \\
\end{array}$ & 11 & 34 & $\begin{array}{c}0.425 \\
\mathrm{a} \\
\pm 0.072\end{array}$ & $\begin{array}{c}1.054 \\
\mathrm{a} \\
\pm 0.072\end{array}$ & 14 \\
\hline M & $\begin{array}{c}2.822 \\
\mathrm{c} \\
\pm 0.126 \\
\end{array}$ & 10 & 33 & $\begin{array}{c}0.301 \\
\mathrm{~b} \\
\pm 0.018 \\
\end{array}$ & $\begin{array}{c}0.875 \\
\mathrm{c} \\
\pm 0.083 \\
\end{array}$ & 14 \\
\hline $\mathbf{S}+\mathbf{M}$ & $\begin{array}{c}3.193 \\
\mathrm{~b} \\
\pm 0.155 \\
\end{array}$ & 11 & 34 & $\begin{array}{c}0.353 \\
\mathrm{~b} \\
\pm 0.012\end{array}$ & $\begin{array}{c}1.003 \\
\mathrm{~b} \\
\pm 0.092 \\
\end{array}$ & 14 \\
\hline L.S.D. & 0.18 & -- & -- & 0.06 & 0.0027 & -- \\
\hline
\end{tabular}

\section{Effect of tested materials followed by mulberry leaves on the biological parameters of the silkworm Bombyx mori L.:}

The demonstrated results in Table 5, proved a significant difference in the mean weight of mature larvae. Larvae fed on mixture of $\left(\mathrm{S}+\mathrm{M}^{*}\right)$ diet, also, $\left(\mathrm{S}^{*}\right)$ diet gave the heaviest mean weight (2.834 and $2.807 \mathrm{~g}$. respectively).

The fresh weights of silk glands as well as pupal weights exhibited a same trend of results, where the $\left(\mathrm{S}^{*}\right)$ diet gave the heaviest weight $(0.551$ and $0.950 \mathrm{~g}$. in respect). Insignificant difference was recorded with the mixture $\left(S+\mathrm{M}^{*}\right)$. While, the $\left(\mathrm{M}^{*}\right)$ diet gave the lightest weight of (0.449 and $0.842 \mathrm{~g}$. respectively). 
As shown in Table, 5 the shortest fifth instar and larval durations (10 and 33 days in respect) were obtained when larvae fed on $\left(\mathrm{M}^{*}\right)$ and $\left(\mathrm{S}+\mathrm{M}^{*}\right)$ diet.

In agreement with, Horie and Watanabe (1983) who reported that larval growth in Bombyx mori was largely dependent on the dietary protein, the increase in body and fresh silk gland weights reached their maximum on diet containing soybean. ElHattab (2002) also, indicated that the fifth larval instar fed on diet contained palm date pollen grains + soybean meal gave the highest significant weights of larvae, silk glands and pupae.

Table 5: Effect of tested materials in semi-artificial followed by natural diet on the inspected biological parameters of Bombyx mori L.

\begin{tabular}{|c|c|c|c|c|c|c|}
\hline Treatments & $\begin{array}{c}\text { Weight of } \\
\text { larvae (g.) } \\
\text { A }\end{array}$ & $\begin{array}{c}5^{\text {th }} \text { instar } \\
\text { duration } \\
\text { (days) }\end{array}$ & $\begin{array}{c}\text { Larval } \\
\text { duration } \\
\text { (days) }\end{array}$ & $\begin{array}{l}\text { Weight of } \\
\text { silk gland } \\
\text { (g.) B }\end{array}$ & $\begin{array}{l}\text { Weight of } \\
\text { pupa (g.) } \\
\text { A }\end{array}$ & $\begin{array}{c}\text { Pupal } \\
\text { duration } \\
\text { (days) }\end{array}$ \\
\hline$S^{*}$ & $\begin{array}{c}2.807 \\
\mathrm{a} \\
\pm 0.283\end{array}$ & 11 & 34 & $\begin{array}{c}0.531 \\
\mathrm{a} \\
\pm 0.082\end{array}$ & $\begin{array}{c}0.950 \\
\mathrm{a} \\
\pm 0.113\end{array}$ & 14 \\
\hline M* & $\begin{array}{c}2.643 \\
\mathrm{~b} \\
\pm 0.258 \\
\end{array}$ & 10 & 33 & $\begin{array}{c}0.463 \\
\mathrm{~b} \\
\pm 0.085\end{array}$ & $\begin{array}{c}0.842 \\
\mathrm{~b} \\
\pm 0.099\end{array}$ & 14 \\
\hline $\mathbf{S}+\mathbf{M}^{*}$ & $\begin{array}{c}2.834 \\
\mathrm{a} \\
\pm 0.294 \\
\end{array}$ & 10 & 33 & $\begin{array}{c}0.482 \\
\mathrm{a} \\
\pm 0.082\end{array}$ & $\begin{array}{c}0.888 \\
\mathrm{ab} \\
\pm 0.113 \\
\end{array}$ & 14 \\
\hline L.S.D. & 0.032 & -- & -- & 0.097 & 0.099 & -- \\
\hline
\end{tabular}

These results are also in agreement with El-Sayed et al (1993) and El-Hattab (2002) who reported that the different source of protein affects the periods of larval and pupal durations.

Effect of the tested materials on silk and egg production of Bombyx mori L.

Significant differences between the mean weights of cocoons and fresh cocoon shells were observed (Table 6). The $5^{\text {th }}$ larval instar fed on (S) and mixture (S+M) diet showed insignificant difference in the averages fresh cocoon and cocoon shell weights. While, the (M) diet gave the lightest weights of (1.006 and $0.13 \mathrm{~g}$.) in respect.

Table 6: Effect of tested materials in semi-artificial diet on silk and production of silkworm Bombyx mori

\begin{tabular}{|c|c|c|c|c|}
\hline Treatments & $\begin{array}{l}\text { Weight of } \\
\text { cocoon (g.) A }\end{array}$ & $\begin{array}{l}\text { Weight of } \\
\text { cocoon shell } \\
\text { (g.) } \mathrm{A}\end{array}$ & $\begin{array}{c}\text { No. of } \\
\text { deposited } \\
\text { eggs } B\end{array}$ & $\underset{\%}{\text { Mortality }}$ \\
\hline $\mathbf{S}$ & $\begin{array}{c}1.26 \\
\mathrm{a} \\
\pm 20.032\end{array}$ & $\begin{array}{c}0.206 \\
\mathrm{a} \\
\pm 0.023\end{array}$ & $\begin{array}{c}391 \\
\mathrm{a} \\
\pm 53.254\end{array}$ & 6 \\
\hline M & $\begin{array}{c}1.006 \\
\mathrm{~b} \\
\pm 0.081\end{array}$ & $\begin{array}{c}0.130 \\
b \\
\pm 0.026\end{array}$ & $\begin{array}{c}272.6 \\
b \\
\pm 23.723\end{array}$ & 8 \\
\hline $\mathbf{S}+\mathbf{M}$ & $\begin{array}{c}1.237 \\
\mathrm{a} \\
\pm 0.088\end{array}$ & $\begin{array}{c}0.234 \\
\mathrm{a} \\
\pm 0.041\end{array}$ & $\begin{array}{c}315 \\
b \\
\pm 39.140\end{array}$ & 8 \\
\hline L.S.D. & 0.075 & 0.029 & 55.87 & -- \\
\hline $\begin{array}{l}\mathrm{S}=\text { Soybean } \\
\text { Each value re }\end{array}$ & \multicolumn{4}{|c|}{$\begin{array}{l}\quad \mathrm{M}=\text { Mushroom } \mathrm{S}+\mathrm{M}=\text { mixture } \\
\text { s the mean } \pm \mathrm{S} . \mathrm{D} \text {. of } \mathrm{A}=10, \mathrm{~B}=5 \text { replicates. }\end{array}$} \\
\hline
\end{tabular}


As shown in Table 6, the utmost increase rate of deposited eggs (391 eggs/female) was counted for the treatment of (S) diet. The (M) meal diet was always the least effective one.

A mortality of $(8 \%)$ was found for the diets of $(\mathrm{M})$ and the mixture $(\mathrm{S}+\mathrm{M})$ (Table 6).

\section{Effect of the tested materials followed by mulberry leaves on silk and egg production of Bombyx mori $\mathrm{L}$.}

The same trend of results were also revealed for the tested materials of soybean $\left(\mathrm{S}^{*}\right)$, mushroom $\left(\mathrm{M}^{*}\right)$ and mixture $\left(\mathrm{S}+\mathrm{M}^{*}\right)$ diets followed by natural diet. As shown in Table 7, the measured weights of fresh cocoon were the heaviest in the larvae fed on $\left(\mathrm{S}^{*}\right)$ diet $\left(1.166 \mathrm{~g}\right.$.) while, lightest weights $\left(1.03 \mathrm{~g}\right.$.) were given to $\left(\mathrm{M}^{*}\right)$ diet.

No significant differences were considered between tested materials in the weights of cocoon shell.

Highest numbers of deposited eggs per female moths were obtained from the treatments of larvae fed on $\left(\mathrm{S}^{*}\right)$ and mixture of $\left(\mathrm{S}+\mathrm{M}^{*}\right)$ diets $(380$ and 335.6 eggs/female respectively). Table 7 , also show a mortality of $(6 \%)$ in the $\left(\mathrm{M}^{*}\right)$ diet.

These results are in accordance with those reported by Horie et al (1971) and ElHattab (2002) that the elevation of dietary protein resulted in the acceleration of growth and silk production. Also, El-Hattab (1985); El-Karaksy et al (1989); ElSayed (1993); Moustafa et al (1997); El-Sayed (1999) and El-Hattab (2002) proved that the type of protein source material in the semi-artificial diet, affected the weights of cocoon, cocoon shells and number of deposited eggs.

Table 7: Effect of tested materials in semi-artificial diet followed by natural diet on silk and production of silkworm Bombyx mori L.

\begin{tabular}{|c|c|c|c|c|}
\hline Treatments & $\begin{array}{c}\text { Weight of } \\
\text { cocoon (g.) } \\
\text { A }\end{array}$ & $\begin{array}{l}\text { Weight of } \\
\text { cocoon shell } \\
\text { (g.) A }\end{array}$ & $\begin{array}{c}\text { No. of } \\
\text { deposited } \\
\text { eggs B }\end{array}$ & $\begin{array}{c}\text { Mortality } \\
\%\end{array}$ \\
\hline $\mathrm{S}^{*}$ & $\begin{array}{c}1.166 \\
\mathrm{a} \\
\pm 0.086 \\
\end{array}$ & $\begin{array}{c}0.206 \\
\pm 0.023 \\
\end{array}$ & $\begin{array}{c}380 \\
\mathrm{a} \\
\pm 56.124 \\
\end{array}$ & 5 \\
\hline $\mathbf{M}^{*}$ & $\begin{array}{c}1.03 \\
\mathrm{~b} \\
\pm 0.132\end{array}$ & $\begin{array}{c}0.187 \\
b \\
\pm 0.068\end{array}$ & $\begin{array}{c}312.8 \\
b \\
\pm 22.620\end{array}$ & 6 \\
\hline $\mathbf{S}+\mathbf{M} *$ & $\begin{array}{c}1.078 \\
\mathrm{ab} \\
\pm 0.119\end{array}$ & $\begin{array}{c}0.189 \\
\pm 0.061\end{array}$ & $\begin{array}{c}335.6 \\
a \\
\pm 24.835\end{array}$ & 5 \\
\hline L.S.D. & 0.104 & 0.055 & 52.04 & -- \\
\hline
\end{tabular}

1. $\mathrm{S}=$ Soybean $\mathrm{M}=$ Mushroom $\mathrm{S}+\mathrm{M}=$ mixture

2. $\quad *=$ larvae fed on semi-artificial diet followed by natural diet.

3. Each value represents the mean \pm S.D. of $A=10, B=5$ replicates.

4. Means followed by same letter(s) are not significantly different.

\section{REFERENCES}

Akhtar, M. and A. Asghar (1972). Nutritional requirements of silkworms Bombyx mori L. Pak. Zool. 4 (2): $101-107$.

El-Hattab, Samia M. (1985). Biological studies on the eri-silkworm Phiolsamia ricini Boisd. with special reference to its nutritional requirements. Ph. D. Thesis, Fac. Agric. Alex. Univ.

El-Hattab, Samia M. (2002). Evaluation of various kinds of dietary proteins in semiartificial diets on the mulberry silkworm Bombyx mori L. $2^{\text {nd }}$ Int. conf., Plant Protection Res. Institute, Cairo, Egypt, 21 - 24 December. 
El-Karaksy, I. A.; Samia M. El-Hattab and Soad M. Moustafa (1989). Eri-silkworm Philosamia ricini Boisd. powdered pupae as an important source of protein in its semi-artificial diet. Seventh Arab Pesticide conf., Tanta Univ. 118 - 125.

El-Sayed, Nagda A. A.; Soad M. Moustafa and Samia M. El-Hattab (1993). Effect of new sources of protein on the Eri-silkworm Phiolsamia ricini Boisd. (Lepidoptera : Saturiniidae). Alex. Sci. Exch. 14(3): 115 - 134.

El-Sayed, Nagda A. A. (1999). Evaluation of six mixtures of food additives on some bio-physiological and reproductively parameters of the mulberry silkworm Bombyx mori L. Monofia J. Agric. Res. 24(6): 1971 - 1986.

Fukuda, T. (1963). A semi synthetic diet for eri - silkworm raising. Agric. Biol. Chem. (Tokyo) 27 (9): $601-609$.

Fukuda, T.; M. Suto and Y. Higuchi (1960). Silkworm raising on artificial food. Nature 187 (4738) $669-670$.

Horie, Y.; K. Watanabe and E. Shinohara (1971). Effect of dietary composition on growth, silk glands and components in haemolymph of silkworm. Acta. Seric. Japan 78, $44-50$.

Horie, Y. and K. Watanabe (1983). Effect of various kinds of dietary protein and supplementation with limiting amino acids on growth, haemolymph components and uric acid excretion in the silkworm, Bombyx mori. J. Insect Physiol., 29: 187 - 199.

Ito, T. and T. Inokuchi (1981). Nutritive effects of D-amino acids on the silkworm, Bombyx mori. J. Insect Physiol., 27: 447 - 453.

Krishnaswami, S. (1973). Improved methods of rearing young (Chawki) silkworms, Central silk Board, Bangalore India, p: 24.

Moustafa, Soad M.; Samia M. El-Hattab and Nagda El-Sayed (1997). Nutritional effect of different levels of mulberry leaf powder and dietary soybean in semiartificial diet on silkworm Bombyx mori L. Adv. Agric. Res. 3(1): 37 - 43.

Salem, M. S. (1974). Feeding of silkworm, Philosamia ricini Boisd. with consideration to silk productivity. Ph. D. Thesis, Fac. Agric. Cairo Univ.

Snedecor, G. W. (1956). Statistical methods. $5^{\text {th }}$ ed., lowa State University Press, lowa, pp. 534.

\section{ARABIC SUMMARY}

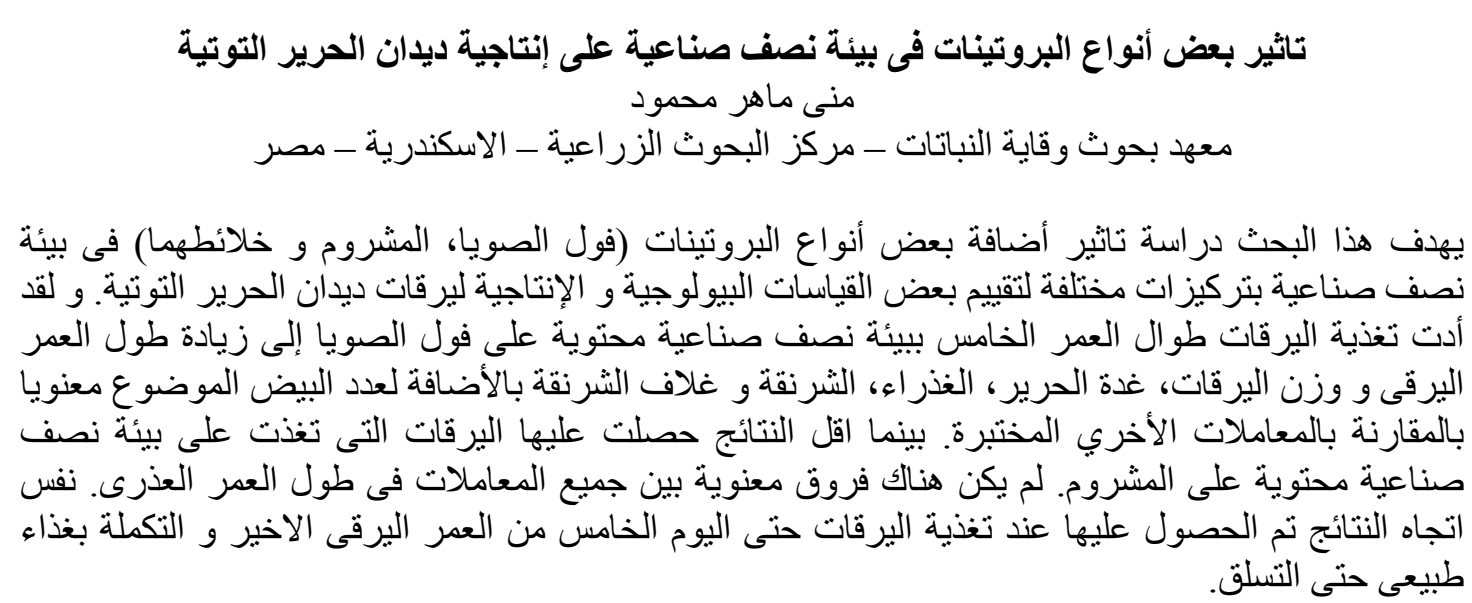

